\title{
Ultra Upper And Lower Contra Continuous Multifunction
}

\author{
${ }^{1}$ N.Durgadevi, ${ }^{2}$ R.Rajrajeswari And ${ }^{3}$ P.Thangavelu. \\ ${ }_{1,2}$ Department of Mathematics, Sri Parasakthi College for Women, Courtallam - 627802, TamilNadu, INDIA. \\ ${ }^{3}$ Department of Mathematics, Karunya University, Coimbatore, TamilNadu, INDIA.
}

Abstract:The aim of this paper is to study the ultra contra continuous multifunction.

Keywords and Phrases: ultra upper contra continuous and ultra lower contra continuous multifunction.

\section{Introduction and Preliminaries}

"Bitopology" is a new concept introduced by Kelly [2] in the year 1963. He defined the topologies with the help of quasi metrics. Later, instead of taking the topologies defined on quasi metrics, researcher tried the study of bitopological spaces with any two topologies omitting the quasi metrics. Almost all the properties of classical topologies were studied using the pairwise concept, the definition of $(1,2) \alpha$ - open sets introduced by Thivagar [3], in the year 1991, opened a new era of research in bitopology. He also defined $(1,2) \alpha-$ continuous function and its weaker and stronger forms between two bitopological spaces. Continuity and multifunction are two basic properties in general topology and set valued analysis. Contra continuous in general topology was introduced and investigated by Dontchev in 1996. That concept was extended to bitopological spaces by Ekici in 2008. By multifunction, we mean a map- ping from a point to a set.

The main purpose of this article is to define and to generalize the ultra- upper and ultra-lower contra continuous multifunction in bitopological spaces. Throughout this paper, $\mathrm{X}$ means $(\mathrm{X}, \tau)$, where $\mathrm{X}$ is a non empty set and $\tau$ is the topology defined on it. By $\mathrm{Y}$, we mean the bitopological space $(\mathrm{Y}, \sigma 1, \sigma 2)$,

where $\mathrm{Y}$ is a non empty set with two topologies $\sigma 1$ and $\sigma 2$ defined on it.

2000 Math. Subject Classification: 54C10, 54C08.

Definition 1.1. Let A be a subset of a bitopological space (Y, $\sigma 1, \sigma 2)$. Then A is said to be [3] (i) $\sigma 1 \sigma 2$-open if $\mathrm{A} \square \in \sigma 1 \cup \sigma 2$,

(ii) $\sigma 1 \sigma 2$ - closed if $A c \square \in \sigma 1 \cup \sigma 2$,

(iii) $(1,2) \alpha$ - open or ultra - open if $\mathrm{A} \square \subseteq \sigma 1$ - Int $(\sigma 1 \sigma 2-\mathrm{Cl}(\sigma 1$-Int (A))), where $\sigma 1$ -

Int (A) is the interior of A with respect to the topology $\sigma 1$ and $\sigma 1 \sigma 2-\mathrm{Cl}(\mathrm{A})$ is the intersection of all $\sigma 1 \sigma 2$ closed sets containing A. Also A is said to be $(1,2) \alpha$ - closed if Ac is $(1,2) \alpha$ - open.

(iv) $\operatorname{Int}(1,2) \alpha(\mathrm{A})$ is the union of all $(1,2) \alpha$ - open sets contained in A.

(v) $\mathrm{Cl}(1,2) \alpha(\mathrm{A})$ is the intersection of all $(1,2) \alpha$ - closed sets containing $\mathrm{A}$.

The set of all $(1,2) \alpha$ - open sets are denoted as $(1,2) \alpha \mathrm{O}(\mathrm{X})$ and if this set forms a topology, then $\mathrm{X}$ is called as an ultra space.

Definition 1.2. An ultra multifunction [5] Fu: $(\mathrm{X}, \tau) \square \rightarrow(\mathrm{Y}, \sigma 1, \sigma 2)$ is a point to a set correspondence and is assumed that $\mathrm{Fu}(\mathrm{x})=\phi$ for all $\mathrm{x} \square \in \mathrm{X}$.

Definition 1.3. The image set $\mathrm{U} \square \subset \mathrm{X}$ of the multifunction $\mathrm{Fu}: \mathrm{X} \square \rightarrow \mathrm{Y}$ is defined [5] by $\mathrm{Fu}(\mathrm{U})=\square \cup\{\mathrm{Fu}(\mathrm{x}) /$ $\mathrm{x} \square \in \mathrm{U} \square\}$.

Definition 1.4. For an ultra multifunction Fu, the upper and lower inverse [5]

of Fu is defined for any set $\mathrm{V} \square \subseteq \mathrm{Y}$, as $\mathrm{Fu}+(\mathrm{V})=\square\{\mathrm{x} \square \in \mathrm{X} / \mathrm{Fu}(\mathrm{x}) \square \subseteq \mathrm{V} \square\} \square$ and $\mathrm{Fu}-(\mathrm{V})$

$=\square\{\mathrm{x} \square \in \mathrm{X} / \mathrm{Fu}(\mathrm{x}) \cap \mathrm{V}=\phi\}$.

Lemma1.5. For any ultra multifunction $\mathrm{Fu}+(\mathrm{V}) \subseteq \mathrm{Fu}-(\mathrm{V})$. This result is proved in [5].

Definition 1.6. Let A be a non-empty subset of a space X. Then $(1,2) \alpha-$ kernal of $A$ or ultra kernal of $A[8]$ and is denoted by $(1,2) \alpha-\operatorname{Ker}(A)$ and is defined as $(1,2) \alpha-\operatorname{Ker}(A)=\square \cap\{\mathrm{G} \square \in$ $(1,2) \alpha \mathrm{O}(\mathrm{X}) / \mathrm{A} \square \subseteq \mathrm{G}\}$. 
Definition1.7. An ultra multifunction Fu: $\mathrm{X} \square \rightarrow \mathrm{Y}$ is said to be ultra upper continuous [resp. ultra lower continuous] [5] if for any $(1,2) \alpha$ - open set $\mathrm{V}$ of $\mathrm{Y}$, there exists an open set $\mathrm{G}$ of $\mathrm{X}$ containing $\mathrm{x}$ such that $\mathrm{Fu}(\mathrm{G})$ $\square \subset \mathrm{V}$ [resp.

$\mathrm{Fu}(\mathrm{x}) \square \cap \mathrm{V}=\phi$ for all $\mathrm{x} \square \in \mathrm{G}]$.

Definition1.8. An ultra multifunction $\mathrm{Fu}: \mathrm{X} \square \rightarrow \mathrm{Y}$ is said to be ultra upper weakly continuous [resp. ultra lower weakly continuous] [9] at the point $\mathrm{x} \square \in \mathrm{X}$, if for any $(1,2) \alpha$ - open set $\mathrm{V}$ of $\mathrm{Y}$ with $\mathrm{Fu}(\mathrm{x}) \square \subset \mathrm{V}$, there exists an open set $\mathrm{G}$ of $\mathrm{X}$ containing $\mathrm{x}$ such that $\mathrm{Fu}(\mathrm{G}) \square \subset \mathrm{Cl}(1,2) \alpha(\mathrm{V})$ for all $\mathrm{x} \square \in \mathrm{G}[\operatorname{resp}$. $\mathrm{Fu}(\mathrm{x}) \square \cap$ $\square \mathrm{Q}(1,2) \alpha(\mathrm{V})=\phi$ for all $\mathrm{x} \square \in \mathrm{G}]$.

\section{Ultra upper (lower) contra continuous multifunction}

In this section, we introduced two new forms of contra continuous multifunction in bitopological spaces and studied their properties.

Definition2.1. An ultra multifunction Fu: $\mathrm{X} \square \rightarrow \mathrm{Y}$ is said to be ultra upper contra continuous (u.u.c.c) at $\mathrm{X} \square \epsilon$ $\mathrm{X}$ if for each $(1,2) \alpha$ - closed set $\mathrm{A}$ such that $\mathrm{X} \square \in \mathrm{Fu}+(\mathrm{V})$ there exists an open set $\mathrm{G}$ of $\mathrm{X}$ containing $\mathrm{x}$ such that $\mathrm{Fu}(\mathrm{G}) \square \subset \mathrm{V}$.

Definition2.2. An ultra multifunction Fu: $\mathrm{X} \square \rightarrow \mathrm{Y}$ is said to be ultra lower contra continuous (u.1.c.c) at $\mathrm{X} \square \in \mathrm{X}$ if for each $(1,2) \alpha$ - closed set $\mathrm{V}$ containing $\mathrm{Fu}(\mathrm{x})$ and $\mathrm{Fu}(\mathrm{x}) \square \cap \mathrm{V}=\phi$ there exists an open set $\mathrm{G}$ containing $\mathrm{x}$ such that $\mathrm{Fu}(\mathrm{y}) \square \cap \mathrm{V}=\phi$ for all $\mathrm{y} \square \in \mathrm{G}$.

$\mathrm{F}$ is said to be ultra upper(lower) contra continuous on $\mathrm{X}$ if $\mathrm{F}$ has this property at each point of $\mathrm{X}$.

Example2.3. Let $\mathrm{X}=\square\{1,2,3\}$ with the topology $\tau=\square\{\phi, \mathrm{X}, \square\{1\}\}$ and $\mathrm{Y}=\{\mathrm{a}, \mathrm{b}, \mathrm{c}\}$ with two topologies $\sigma 1$ $=\{\phi, \mathrm{Y}, \square\{\mathrm{a}\}\}$ and $\sigma 2=\square\{\phi, \mathrm{Y}, \square\{\mathrm{a}\}, \square\{\mathrm{b}, \mathrm{c}\}\}$. Define an ultra multifunction Fu: $\mathrm{X} \square \rightarrow \mathrm{Y}$ as $\mathrm{Fu}(1)=\square\{\mathrm{b}\}$, $\mathrm{Fu}(2)=\square\{\mathrm{a}, \mathrm{c}\}, \mathrm{Fu}(3)=\{\mathrm{a}, \mathrm{b}\}$. Here, Fu is both ultra upper contra continuous and ultra lower contra continuous.

Remark2.4. Ultra upper contra continuity implies ultra lower contra conti-nuity.

Proof: Let Fu: $\mathrm{X} \square \rightarrow \mathrm{Y}$ be an ultra upper contra continuous multifunction and $\mathrm{x} \in \mathrm{X}$. Then, let $\mathrm{V}$ be any $(1,2) \alpha$ - open set in $Y$ such that $\mathrm{x} \square \in \mathrm{Fu}+(\mathrm{V})$. Then by definition, there exists an open set $\mathrm{G}$ of $\mathrm{X}$ containing $\mathrm{x}$ such that $\mathrm{Fu}+(\mathrm{G}) \square \subset \mathrm{V}$ implies $\mathrm{Fu}(\mathrm{y}) \square \square \cap \mathrm{V}=\phi$ for all $\mathrm{y} \square \in \mathrm{G}$.

But the converse is not true as shown in the following example.

Example2.5. In Example 2.3, define an ultra multifunction $\mathrm{Fu}: \mathrm{X} \square \rightarrow \mathrm{Y}$ as $\mathrm{Fu}(1)=\square\{\mathrm{a}\}, \mathrm{Fu}(2)=\square\{\mathrm{b}, \mathrm{c}\}, \mathrm{Fu}(3)$ $=\square\{\mathrm{b}\}$. Here, Fu is ultra lower contra continuous but it is not ultra upper contra continuous.

Theorem2.6. For an ultra multifunction Fu: $\mathrm{X} \square \rightarrow \mathrm{Y}$, the following are equivalent.

(i) Fu is ultra upper contra continuous.

(ii) $\mathrm{Fu}+(\mathrm{A})$ is open in $\mathrm{X}$ for any $(1,2) \alpha$ - closed set $\mathrm{A} \square \subset \mathrm{Y}$.

(iii) $\mathrm{Fu}-(\mathrm{V})$ is closed in $\mathrm{X}$ for any $(1,2) \alpha$ - open set $\mathrm{V} \square \subset \mathrm{Y}$.

(iv) for each $\mathrm{x} \square \in \mathrm{X}$ and each $(1,2) \alpha$ - closed set $\mathrm{A}$ containing $\mathrm{Fu}(\mathrm{x})$, there

exists an open set $\mathrm{G}$ containing $\mathrm{x}$ such that $\mathrm{Fu}(\mathrm{y}) \square \subset \mathrm{A}$ for all $\mathrm{y} \square \in \mathrm{G}$.

Proof: (i) $\Leftrightarrow$ (ii) Let $\mathrm{A}$ be any $(1,2) \alpha$-closed set in $\mathrm{Y}$ and $\mathrm{x} \square \in \mathrm{Fu}+(\mathrm{A})$. Since $\mathrm{Fu}$ is u.u.c.c there exists an open set $\mathrm{G}$ containing $\mathrm{x}$ such that $\mathrm{G} \square \subset \square \mathrm{Fu}+(\mathrm{A})$. Thus $\mathrm{Fu}+(\mathrm{A})$ is open.

(ii) $\Leftrightarrow$ (iii) This follows from the fact that $\mathrm{Fu}+(\mathrm{Y} / \mathrm{V})=\mathrm{X} / \mathrm{Fu}-(\mathrm{V})$ for every subset $\mathrm{V}$ of $\mathrm{Y}$ is open. This implies that $\mathrm{Fu}-(\mathrm{V})$ is closed.

(iii) $\Leftrightarrow$ (iv) Let $\mathrm{x} \square \in \mathrm{X}$ and A be any $(1,2) \alpha$ - closed set containing $\mathrm{Fu}(\mathrm{x})$. Since A is $(1,2) \alpha-$ closed $\mathrm{Y} / \mathrm{A}$ is $(1,2) \alpha$ - open. This implies that $\mathrm{Fu}-(\mathrm{Y} / \mathrm{A})$ is closed in $\mathrm{X}$. Then $\mathrm{Fu}-(\mathrm{Y} / \mathrm{A})=\mathrm{X} / \mathrm{Fu}+(\mathrm{A})$ is closed in $\mathrm{X}$. Therefore $\mathrm{Fu}+(\mathrm{A})$ is open in $\mathrm{X}$. So, there exists an open set $\mathrm{G}$ of $\mathrm{X}$ such that $\mathrm{G} \square \subset \mathrm{Fu}+(\mathrm{A})$ and $\mathrm{Fu}(\mathrm{G}) \square \square \subseteq \mathrm{A} \Rightarrow$ $\mathrm{Fu}(\mathrm{y}) \square \subseteq \mathrm{A}$ for all $\mathrm{y} \square \in \mathrm{G}$.

(iv) $\square \Leftrightarrow$ (i) It is obvious.

Theorem2.7. For an ultra multifunction Fu: $\mathrm{X} \square \rightarrow \mathrm{Y}$, the following are equivalent. 
$\mathrm{Fu}$ is ultra lower contra continuous.

(ii) $\mathrm{Fu}-(\mathrm{A})$ is open for any $(1,2) \alpha$-closed set $\mathrm{A} \subset \mathrm{Y}$.

(iii) $\mathrm{Fu}+(\mathrm{V})$ is closed in $\mathrm{X}$ for any $(1,2) \alpha$-open set $\mathrm{V} \square \subset \mathrm{Y}$.

(iv) for each $\mathrm{x} \square \in \mathrm{X}$ and each $(1,2) \alpha$ - closed set A containing $\mathrm{Fu}(\mathrm{x}) \square \cap \mathrm{V}=\phi$, there exists an open set $\mathrm{G}$ containing $\mathrm{x}$ such that $\mathrm{Fu}(\mathrm{y}) \square \cap \mathrm{A}=\phi$ for all $\mathrm{y} \square \in \mathrm{G}$.

Proof: Similar to Theorem 2.6

Lemma2.8. For any two subsets A, B of a bitopological space $(X, \tau 1, \tau 2)$.

The following properties hold: [8]

(i) $\mathrm{x} \square \in(1,2) \alpha-\operatorname{Ker}(\mathrm{A})$ if $\mathrm{A} \cap \mathrm{B}=\phi$ for any $(1,2) \alpha$ - closed set $\mathrm{B}$ containing $\mathrm{x}$.

(ii) If $\mathrm{A} \in(1,2) \alpha \mathrm{O}(\mathrm{X})$, then $\mathrm{A} \square \equiv(1,2) \alpha-\operatorname{Ker}(\mathrm{A})$.

Theorem2.9. Let $\mathrm{Fu}: \mathrm{X} \square \rightarrow \mathrm{Y}$ be an ultra multifunction. If $\mathrm{Cl}(\mathrm{Fu}-(\mathrm{A})) \square \subset \square \mathrm{Fu}-((1,2) \alpha \operatorname{Ker}(\mathrm{A}))$ for every (1, 2) $\alpha$-open subset $\mathrm{A}$ of $\mathrm{Y}$, then $\mathrm{Fu}$ is ultra upper contra continuous.

Proof: Suppose that $\mathrm{Cl}(\mathrm{Fu}-(\mathrm{A})) \square \subset \mathrm{Fu}-((1,2) \alpha \operatorname{Ker}(\mathrm{A}))$ for every subset A of Y. As $\mathrm{A} \square \in(1,2) \alpha \mathrm{O}(\mathrm{Y})$. By Lemma 2.8, $\mathrm{Cl}(\mathrm{Fu}-(\mathrm{A})) \square \subset \mathrm{Fu}-((1,2) \alpha \operatorname{Ker}(\mathrm{A}))=\mathrm{Fu}-(\mathrm{A})$. Thus, $\mathrm{Cl}(\mathrm{Fu}-(\mathrm{A}))=\mathrm{Fu}-(\mathrm{A})$ and hence $\mathrm{Fu}-(\mathrm{A})$ is closed in X. Consequently, by the above Theorem 2.6, Fu is u.u.c.c.

Theorem2.10. Suppose one of the following properties hold for an ultra multifunction $\mathrm{Fu}: \mathrm{X} \square \rightarrow \mathrm{Y}$.

(i) $\mathrm{Fu}(\mathrm{Cl}(\mathrm{A})) \square \subset(1,2) \alpha-\operatorname{Ker}(\mathrm{Fu}(\mathrm{A}))$ for every subset $\mathrm{A}$ of $\mathrm{X}$.

(ii) $\mathrm{Cl}(\mathrm{Fu}+(\mathrm{V})) \square \subset(\mathrm{Fu}+((1,2) \alpha-\operatorname{Ker}(\mathrm{V}))$ for every subset $\mathrm{V}$ of $\mathrm{Y}$.

Then $\mathrm{Fu}$ is ultra lower contra continuous.

Proof: Given $\mathrm{A} \square \subseteq \mathrm{X}$ and $\mathrm{Fu}(\mathrm{Cl}(\mathrm{A})) \square \subset(1,2) \alpha-\operatorname{Ker}(\mathrm{Fu}(\mathrm{A}))$. Now, let $\mathrm{V} \square \subseteq \mathrm{Y}$ and $\mathrm{Fu}(\mathrm{Cl}(\mathrm{Fu}+(\mathrm{V})) \square \subset(1,2) \alpha-$ $\operatorname{Ker}(\mathrm{Fu}(\mathrm{V}))$. Hence, $\mathrm{Fu}(\mathrm{Cl}(\mathrm{Fu}+(\mathrm{V}))) \square \subset \square \square(1,2) \alpha-\operatorname{Ker}(\mathrm{Fu}(\mathrm{Fu}+(\mathrm{V}))) \Rightarrow \mathrm{Cl}(\mathrm{Fu}+(\mathrm{V})) \square \subset \mathrm{Fu}+((1,2) \alpha-\operatorname{Ker}(\mathrm{V}))$ for every subset V of Y. Now, $(1,2) \alpha-\operatorname{Ker}(\mathrm{V})$ is a $(1,2) \alpha-$ open set say A. This implies that $(1,2) \alpha-\operatorname{Ker}$ (V) $\square \equiv$ A. Hence, by the definition of Kernel we get, $\mathrm{Cl}(\mathrm{Fu}+(\mathrm{A}) \square \subseteq \square \mathrm{Fu}+(\mathrm{A})$. Thus, $\mathrm{Fu}+(\mathrm{A})$ is a closed set in $\mathrm{X}$.

By the Theorem 2.6, Fu is ultra lower contra continuous.

Theorem2.11. Let $\mathrm{Fu}: \mathrm{X} \square \rightarrow \mathrm{Y}$ and $\mathrm{Gu}: \mathrm{Y} \square \rightarrow \mathrm{Z}$ be ultra multifunction. If $\mathrm{Fu}$ is ultra upper continuous and $\mathrm{Gu}$ is ultra upper contra continuous, then GuoFu: $\mathrm{X} \square \rightarrow \mathrm{Z}$ is ultra upper contra continuous.

Proof: Let $\mathrm{A} \square \subset \mathrm{Z}$ be a $(1,2) \alpha$ - closed set. We have, $(\mathrm{GuoFu})+(\mathrm{A})=\mathrm{Fu}+(\mathrm{Gu}+(\mathrm{A}))$.

Since, $\mathrm{Gu}$ is ultra upper contra continuous, $\mathrm{Gu}+(\mathrm{A})$ is an $(1,2) \alpha$ - open set. Since Fu is ultra upper continuous, $\mathrm{Fu}+(\mathrm{Gu}+(\mathrm{A}))$ is an $(1,2) \alpha$-open set. Thus, GuoFu is an ultra upper contra continuous multifunction.

Theorem2.12. Let Fu: $\mathrm{X} \square \rightarrow \mathrm{Y}$ and Gu: $\mathrm{Y} \square \rightarrow \mathrm{Z}$ be an ultra multifunction. If Fu is ultra lower continuous and $\mathrm{Gu}$ is ultra lower contra continuous, then GuoFu: $\mathrm{X} \square \rightarrow \mathrm{Z}$ is ultra lower contra continuous.

Proof: Let $\mathrm{A} \square \subset \mathrm{Z}$ be a $(1,2) \alpha$ - closed set. We have, $(\mathrm{GuoFu})-(\mathrm{A})=\mathrm{Fu}-(\mathrm{G}-(\mathrm{A}))$.

Since, $\mathrm{Gu}$ is ultra lower contra continuous, $\mathrm{Gu}-(\mathrm{A})$ is an $(1,2) \alpha$ - open set. Since Fu is ultra lower continuous, $\mathrm{Fu}-(\mathrm{Gu}-(\mathrm{A}))$ is an $(1,2) \alpha$-open set. Thus, GuoFu is ultra lower contra continuous multifunction.

Theorem2.13. Let Fu: $\mathrm{X} \square \rightarrow \mathrm{Y}$ be an ultra multifunction and let $\mathrm{A} \square \subset \mathrm{X}$. If Fu is an ultra lower (upper) contra continuous multifunction then restriction multifunction $\mathrm{Fu} \square \square \mathrm{A}: \mathrm{A} \rightarrow \mathrm{Y}$ is ultra lower (upper) contra continuous.

Proof: Let $\mathrm{B} \square \subset \mathrm{Y}$ be a $(1,2) \alpha$ - closed set and $\mathrm{x} \square \in \mathrm{A}$ and let $\mathrm{x} \square \in \square$ (Fu $\square \square \mathrm{A})-(\mathrm{B})$. Since Fu is lower contra continuous multifunction, then there exists an open set $U$ in $X$ containing $x$ such that $U \square \subset(F u$ $\square \square \mathrm{A})-(\mathrm{B})$. This implies that $\mathrm{x} \square \in \mathrm{U} \square \cap \mathrm{A}$ which is open in A and also $\mathrm{U} \square \cap \mathrm{A} \square \subset(\mathrm{Fu} \square \square \mathrm{A})-(\mathrm{B})$. Thus, $\mathrm{Fu} \square \square \mathrm{A}$ is lower contra continuous. 


\section{Some stronger and weaker forms of contra multifunction}

In this section, we introduced two more new contra continuous multifunctions, named as ultra upper (lower) clopen continuous, which is stronger than ultra upper (lower) contra continuous and ultra upper (lower) weakly continuous multifunction which is weaker than ultra upper (lower) contra continuous respectively. Some of their properties are studied and each function is sustained with suitable examples.

Definition3.1. An ultra multifunction $\mathrm{Fu}: \mathrm{X} \square \rightarrow \mathrm{Y}$ is called ultra upper (lower) clopen continuous if for each $\mathrm{X} \square \in \mathrm{X}$ and each $(1,2) \alpha$ - open set $\mathrm{V}$ such that $\mathrm{x} \square \in \mathrm{Fu}+(\mathrm{V})$ [resp. $\mathrm{x} \square \in \mathrm{Fu}-\mathrm{V}$ ] there exists a clopen set $\mathrm{G}$ containing $\mathrm{x}$ such that $\mathrm{G} \square \subset \mathrm{Fu}+(\mathrm{V})$ [resp. $\mathrm{G} \square \subset \mathrm{Fu}-(\mathrm{V})]$.

Example3.2. Let $\mathrm{X}=\square\{1,2,3\}$ with the topology $\tau=\square\{\phi, \mathrm{X}, \square\{1\}, \square\{2,3\}\}$ and $\mathrm{Y}=\square\{\mathrm{a}, \mathrm{b}, \mathrm{c}\}$ with two topologies $\sigma 1=\square\{\phi, \mathrm{Y} \square\}$ and $\sigma 2=\square\{\phi, \mathrm{Y}, \square\{\mathrm{c}\}\}$. Define a multifunction Fu: $\mathrm{X} \square \rightarrow \mathrm{Y}$ as $\mathrm{Fu}(1)=\square\{\mathrm{a}\}$, $\mathrm{Fu}(2)=\square\{\mathrm{b}, \mathrm{c}\}, \mathrm{Fu}(3)=\square\{\mathrm{c}\}$. Then, Fu is both ultra upper clopen continuous and ultra lower clopen continuous.

Theorem3.3. If $\mathrm{Fu}: \mathrm{X} \square \rightarrow \mathrm{Y}$ is a multifunction and is ultra upper (lower) contra continuous, then Fu is ultra upper (lower) weakly continuous.

Proof: Let $\mathrm{Fu}$ be an ultra upper contra continuous. Also, let $\mathrm{x} \square \in \mathrm{X}$ and $\mathrm{V}$ be any $(1,2) \alpha-$ open set of $\mathrm{V}$ containing $\mathrm{Fu}(\mathrm{x})$. Then, $\mathrm{Cl}(1,2) \alpha(\mathrm{V})$ is a $(1,2) \alpha$ - closed set containing $\mathrm{Fu}(\mathrm{x})$. Since, $\mathrm{Fu}$ is ultra upper contra continuous, by Theorem 2.6, there exists an open set $\mathrm{G}$ containing $\mathrm{x}$ such that $\mathrm{G} \subset \mathrm{Fu}+(\mathrm{Cl}(1,2) \alpha(\mathrm{V}))$. Hence, $\mathrm{Fu}$ is ultra upper weakly continuous.

The proof is similar for ultra lower contra continuous.

Remark3.4. The following holds for an ultra multifunction Fu: $\mathrm{X} \square \rightarrow \mathrm{Y}$



Example3.5. Let $\mathrm{X}=\square\{1,2,3\}$ with the topology $\tau=\square\{\phi, \mathrm{X}, \square\{1\}, \square\{1,2\}\}$ and $\mathrm{Y}=\square\{\mathrm{a}, \mathrm{b}, \mathrm{c}, \mathrm{d}\}$ with two topologies $\sigma 1=\{\phi, \mathrm{Y}, \square\{\mathrm{a}\}, \square\{\mathrm{a}, \mathrm{c}\},\{\mathrm{c}, \mathrm{d}\},\{\mathrm{a}, \mathrm{c}, \mathrm{d}\}\}$ and $\sigma 2=\{\phi, \mathrm{Y},\{\mathrm{b}\}\}$. Define an ultra multifunction $\mathrm{Fu}: \mathrm{X} \square \rightarrow \mathrm{Y}$ as $\mathrm{Fu}(1)=\square\{\mathrm{a}\}, \mathrm{Fu}(2)=\square\{\mathrm{a}, \mathrm{c}\}, \mathrm{Fu}(3)=\square\{\mathrm{a}, \mathrm{c}, \mathrm{d}\}$. Then, it is both ultra upper continuous and ultra lower continuous and also it is an ultra upper weakly continuous and ultra lower weakly continuous but it is not both ultra upper contra continuous and ultra lower contra continuous .

Example3.6. Let $X=\square\{1,2,3\}$ with the topology $\tau=\square\{\phi, X, \square\{1,2\}\}$ and $Y=\{a, b, c, d\}$ with two topologies $\sigma 1=\square\{\phi, \mathrm{Y}, \square\{a\}, \square\{\mathrm{d}\},\{\mathrm{a}, \mathrm{d}\}\}$ and $\sigma 2=\square\{\phi, \mathrm{Y}, \square\{c\}\}$. Define an ultra multifunction Fu: $\mathrm{X} \square \rightarrow \mathrm{Y}$ as $\mathrm{Fu}(1)=\square\{\mathrm{a}\}, \mathrm{Fu}(2)=\square\{\mathrm{b}, \mathrm{c}\}, \mathrm{Fu}(3)=\square\{\mathrm{a}, \mathrm{c}, \mathrm{d}\}$. Then, Fu is ultra upper weakly continuous but it is not ultra upper continuous.

From example 2.3, we have, Fu is both u.u.c.c and u.u.w.c but not u.u.c.

Example3.7. Let $\mathrm{X}=\square\{1,2,3\}$ with the topology $\tau=\{\phi, X,\{1\},\{2,3\}\}$ and $\mathrm{Y}=\square\{\mathrm{a}, \mathrm{b}, \mathrm{c}\}$ with two topologies $\sigma 1=\{\phi, \mathrm{Y}, \square\{\mathrm{a}\}\}$ and $\sigma 2=\square\{\phi, \mathrm{Y}, \square\{\mathrm{a}\},\{\mathrm{b}, \mathrm{c}\}\} .$. Define an ultra multifunction $\mathrm{Fu}: \mathrm{X} \square \rightarrow \mathrm{Y}$ as $\mathrm{Fu}(1)=\square\{\mathrm{a}\}, \mathrm{Fu}(2)=\square\{\mathrm{a}, \mathrm{c}\}, \mathrm{Fu}(3)=\square\{\mathrm{a}, \mathrm{b}\}$. Here, $\mathrm{Fu}$ is both ultra upper contra continuous and ultra lower contra continuous but not ultra upper clopen continuous and also not ultra lower clopen continuous.

\section{The graph multifunction and Applications}

In this section, we derived some properties of ultra upper weakly continuous and ultra lower weakly continuous which can be extended to ultra upper contra continuous and ultra lower contra continuous multifunction. 
Definition4.1. The graph of a multifunction [9] Fu: $\mathrm{X} \square \rightarrow \mathrm{Y}$ is denoted as $\mathrm{FuG}(\mathrm{x})$ and is defined as $\mathrm{FuG}(\mathrm{x})=\square\{\mathrm{x} \square \times \mathrm{Fu}(\mathrm{x})\}$ for $\mathrm{x} \square \in \mathrm{X}$.

Theorem4.2. Let Fu: $\mathrm{X} \square \rightarrow \mathrm{Y}$ be an ultra multifunction. Then FuG is ultra upper weakly continuous in $\mathrm{x} \square \in \mathrm{X}$ if and only if $\mathrm{Fu}$ is ultra upper weakly continuous in $\mathrm{X}$.

Proof: Let Fu be an ultra upper weakly continuous function in $\mathrm{x} \square \in \mathrm{X}$. Let $\mathrm{W} \square \subset \mathrm{X} \square \times \mathrm{Y}$ be a $(1,2) \alpha-$ open set of $\mathrm{X} \square \times \mathrm{Y}$ such that $\square \square \mathrm{x} \square \times \mathrm{Fu}(\mathrm{x}) \square \in \mathrm{W}$. By a $(1,2) \alpha-$ open set $\mathrm{W}$ in $\mathrm{X} \square \times \mathrm{Y}$, we mean $\mathrm{W}=\mathrm{U} \square \times \mathrm{V}$ where $\mathrm{U}$ is open in $\mathrm{X}$ and $\mathrm{V}$ is $(1,2) \alpha$ - open in $\mathrm{Y}$. Now, let $\mathrm{U}$ be an open set of $\mathrm{X}$ containing $\mathrm{X}$ and $\mathrm{V}$ be a $(1,2) \alpha-$ open set of $\mathrm{Y}$ such that $\mathrm{Fu}(\mathrm{x}) \square \subset \mathrm{V}$. As Fu is u.u.w.c, for any $\mathrm{Fu}(\mathrm{x}) \square \subset \mathrm{V}$, there exists an open set $\mathrm{G}$ contained in $\mathrm{U}$ and $\quad \mathrm{Fu}(\mathrm{x}) \square \subset \mathrm{Cl}(1,2) \alpha(\mathrm{V})$ for all $\mathrm{x} \square \in \mathrm{G}$. Hence we have, $\mathrm{Fu}(\mathrm{G}) \square \subset \mathrm{Cl}(1,2) \alpha(\mathrm{V})$. Ultimately, $\square \mathrm{x} \square \times \mathrm{Fu}(\mathrm{x}) \subset \mathrm{G} \square \times \mathrm{Cl}(1,2) \alpha(\mathrm{V}) \square \subset \mathrm{Cl}(\mathrm{G}) \times \mathrm{Cl}(1,2) \alpha(\mathrm{V}) \square \subset \mathrm{Cl}(\mathrm{X} \times \mathrm{Y})(\mathrm{W}) . \mathrm{By} \mathrm{Cl}(\mathrm{X} \times \mathrm{Y})(\mathrm{W})$, we mean the closure of $\mathrm{W}$ in $\mathrm{X} \square \times \mathrm{Y}$. Hence FuG is u.u.w.c.

Conversely, let FuG be u.u.w.c at $\mathrm{X} \square \in \mathrm{X}$. Let $\mathrm{X} \square \times \mathrm{V}$ be a $(1,2) \alpha-$ open set of $\mathrm{X} \square \times \mathrm{Y}$ such that $\mathrm{V}$ is an $(1$, 2) $\alpha$ - open set in $\mathrm{Y}$ containing $\mathrm{Fu}(\mathrm{x})$ and $\square \square \mathrm{x} \square \mathrm{XFu}(\mathrm{x}) \square \subset \mathrm{X} \square \times \mathrm{V}$. $\quad$ Since FuG is u.u.w.c, there exists an open set $\mathrm{U}$ of $\mathrm{X}$ containing $\mathrm{x}$ such that $\square \square \mathrm{x} \square \times \mathrm{Fu}(\mathrm{x}) \square \subset \mathrm{Cl}(\mathrm{X} \times \mathrm{Y})(\mathrm{X} \square \times \mathrm{V}) \square \subset \mathrm{X} \square \times \mathrm{Cl}(1,2) \alpha(\mathrm{V})$ for all $\mathrm{x} \square \in \mathrm{G}$. Hence if $\mathrm{x} \square \in \mathrm{U}$, then $\mathrm{Fu}(\mathrm{U}) \square \subset \mathrm{Cl}(1,2) \alpha(\mathrm{V})$. We conclude that $\mathrm{Fu}(\mathrm{x}) \square \subset \mathrm{Cl}(1,2) \alpha(\mathrm{V})$ for all $\mathrm{x} \square \in$ U. This implies that $\mathrm{Fu}$ is u.u.w.c.

Theorem4.3. The ultra multifunction Fu: $(\mathrm{X}, \tau) \square \rightarrow(\mathrm{Y}, \sigma 1, \sigma 2)$ is u.1.w.c in $\mathrm{X} \square \in \mathrm{X}$ if and only if the graph of the ultra multifunction FuG is u.l.w.c in $\mathrm{X}$.

Proof: Suppose Fu is a u.l.w.c function in $\mathrm{x}$. Let $\mathrm{W} \square \subset \mathrm{X} \square \square \mathrm{Y}$ be a $(1,2) \alpha-$ open set in $\mathrm{X} \square \times \mathrm{Y}$ such that $(\square \mathrm{X} \square \times \mathrm{Fu}(\mathrm{x})) \square \cap \mathrm{W}=\phi$. Then there exists an open set $\mathrm{U}$ of $\mathrm{X}$ and a $(1,2) \alpha$ - open set $\mathrm{V}$ of $\mathrm{Y}$ such that $\mathrm{X} \square \in$ $\mathrm{U}$ and $\mathrm{Fu}(\mathrm{x}) \square \cap \square \mathrm{V}=\phi$ and $\mathrm{U} \square \times \mathrm{V} \square \subset \mathrm{W}$. Since $\mathrm{Fu}$ is u.l.w.c, there exists an open set $\mathrm{G}$ of $\mathrm{X}$ containing $\mathrm{x}$ and contained in $\mathrm{U}$ such that $\mathrm{Fu}(\mathrm{x}) \square \cap \mathrm{Cl}(1,2) \alpha(\mathrm{V})=\phi$ for all $\mathrm{x} \square \in \square \mathrm{G}$. Hence $\mathrm{FuG}(\mathrm{x}) \square \cap \mathrm{G} \square \times \mathrm{Cl}(1,2) \alpha(\mathrm{V})=$ $[\square \mathrm{x} \square \times \mathrm{Fu}(\mathrm{x})] \square \cap[\mathrm{G} \square \times \mathrm{Cl}(1,2) \alpha(\mathrm{V})]=\phi$ for all $\mathrm{x} \square \in \mathrm{G}$. Also $\mathrm{G} \square \cap \mathrm{Cl}(1,2) \alpha(\mathrm{V}) \square \subset \mathrm{U} \square \cap \mathrm{Cl}(1,2) \alpha$ (V) $\square \subset \mathrm{Cl}(\mathrm{U}) \square \cap \mathrm{Cl}(1,2) \alpha(\mathrm{V}) \subset \mathrm{Cl}(\mathrm{X} \times \mathrm{Y})(\mathrm{W})$. Hence $\mathrm{FuG}$ is u.l.w.c.

Conversely, let FuG be u.l.w.c in $\mathrm{x} \square \in \mathrm{X}$ and let $\mathrm{X} \square \times \mathrm{V}$ be a $(1,2) \alpha$ - open set of $\mathrm{X} \square \times \mathrm{Y}$ such that Fu(x) $\square \cap$ $\mathrm{V}=\phi$. The set $\mathrm{X} \square \times \mathrm{V}$ is open in $\mathrm{X} \square \square \times \mathrm{Y}$ and also $\quad[\square \mathrm{x} \square \times \mathrm{Fu}(\mathrm{x})] \square \cap(\mathrm{X} \square \times \mathrm{V})=\phi$. Since FuG is u.l.w.c, there exists an open set $\mathrm{G}$ of $\mathrm{X}$ containing $\mathrm{x}$ such that $\mathrm{FuG}(\mathrm{x}) \square \cap \mathrm{Cl}(\mathrm{X} \times \mathrm{Y})(\mathrm{X} \square \times \mathrm{V})=\phi$ for all $\mathrm{x} \square \in$ $\mathrm{X}$. Again $\mathrm{Cl}(\mathrm{X} \times \mathrm{Y})(\mathrm{X} \square \times \mathrm{V})=\mathrm{Cl}(\mathrm{X}) \square \times \mathrm{Cl}(1,2) \alpha(\mathrm{V})=\mathrm{X} \square \times \mathrm{Cl}(1,2) \alpha(\mathrm{V})$. It follows that $\mathrm{Fu}(\mathrm{x}) \square \cap \mathrm{Cl}(1$, 2) $\alpha(\mathrm{V})=\phi$ for all $\mathrm{X} \square \in \mathrm{G}$. Hence Fu is u.l.w.c.

Theorem4.4. Let Fu: $\mathrm{X} \square \rightarrow \mathrm{Y}$ be an ultra multifunction. Then FuG is ultra upper (lower) contra continuous in $\mathrm{X} \square \in \mathrm{X}$ then $\mathrm{Fu}$ is ultra upper (lower) contra continuous in $\mathrm{X}$.

Proof: Since u.u.c.c $\square \Rightarrow$ u.u.w.c, the conclusion follows from the above Theorem 4.3.

Definition4.5. An ultra multifunction [9] $\mathrm{Fu}: \mathrm{X} \square \rightarrow \mathrm{Y}$ is said to be ultra punctually connected if $\mathrm{Fu}(\mathrm{x})$ is connected for each $\mathrm{x} \square \in \mathrm{X}$.

Theorem4.6. If Fu: $\mathrm{X} \square \rightarrow \mathrm{Y}$ is an ultra upper (lower) weakly continuous punctually connected surjective multifunction and $\mathrm{X}$ is connected, then $\mathrm{Y}$ is connected.

Proof: Suppose Fu is u.u.w.c and $\mathrm{Y}$ is not ultra connected, then there exists two non-empty $(1,2) \alpha$ - open sets $\mathrm{A}$ and $\mathrm{B}$ such that $\mathrm{Y}=\mathrm{A} \square \cup \mathrm{B}$ also $\mathrm{A}$ and $\mathrm{B}$ are both $(1,2) \alpha$-open and $(1,2) \alpha$ - closed. As Fu is surjective, $\mathrm{X}=$ $\mathrm{Fu}+(\mathrm{Y})=\mathrm{Fu}+(\mathrm{A} \square \cup \mathrm{B})$. Since $\mathrm{Fu}$ is ultra punctually connected for any $\mathrm{x} \square \in \mathrm{X}, \mathrm{Fu}+(\mathrm{x}) \square \subset \mathrm{A} \square \cup \mathrm{B}, \mathrm{Fu}+$ (x) $\square \subset \mathrm{A}$ or $\mathrm{Fu}+(\mathrm{x}) \square \subset \mathrm{B}$ which implies $\mathrm{x} \square \in \mathrm{Fu}+(\mathrm{A})$ or $\mathrm{x} \square \in \mathrm{Fu}+(\mathrm{B})$. Hence we have, $\mathrm{X}=\mathrm{Fu}+(\mathrm{A}) \square \cup$ $\mathrm{Fu}+(\mathrm{B})$. As $\mathrm{Fu}+$ is surjective, there exists an $\mathrm{x} \square \in \mathrm{X}$ such that $\mathrm{Fu}+(\mathrm{x}) \square \subset \mathrm{A}$ and there exists an $\mathrm{x}$ such that $\mathrm{Fu}+(\mathrm{x}) \subset \mathrm{B}$ and so $\mathrm{Fu}+(\mathrm{A})$ and $\mathrm{Fu}+(\mathrm{B})$ are nonempty. By Theorem 2.3 [9], $\mathrm{Fu}+(\mathrm{A}) \square \subset \square \operatorname{Int}(\mathrm{Fu}+(\mathrm{Cl}(1,2) \alpha$ $(\mathrm{A})))$. As $\mathrm{A}$ is $(1,2) \alpha$-closed, we get $\mathrm{Fu}+(\mathrm{A}) \square \subset \operatorname{Int}((\mathrm{Fu}+(\mathrm{A})))$. Hence $\mathrm{Fu}+(\mathrm{A})$ is both open and closed. Similarly, we can say that $\mathrm{Fu}+(\mathrm{B})$ is also open. Hence $\mathrm{X}$ is separable, which is a contradiction. 
Now, let $\mathrm{Fu}$ be u.l.w.c. Assume $\mathrm{Y}=\mathrm{A} \square \cup \mathrm{B}$. If $\mathrm{x} \square \in \mathrm{Fu}+(\mathrm{A})$, then $\mathrm{x} \square \in \mathrm{Fu}-(\mathrm{A})$

(by Lemma $1.5)$ and thus $\mathrm{Fu}(\mathrm{x}) \square \cap \mathrm{A}=\phi$. Then there exists an open set $\mathrm{G}$ of $\mathrm{X}$, such that $\mathrm{Fu}(\mathrm{x}) \square \cap \mathrm{Cl}(1,2) \alpha(\mathrm{A})=\phi$, for all $\mathrm{x} \square \in \mathrm{G}$. But $\mathrm{Cl}(1,2) \alpha(\mathrm{A})=\mathrm{A}$ and so $\mathrm{Fu}(\mathrm{x}) \square \cap \mathrm{A}=\phi$, for all $\mathrm{x} \square \in \mathrm{G}$. Also $\mathrm{Fu}$ is punctually connected, from $\mathrm{Fu}+(\mathrm{A}) \square \cap \mathrm{Fu}+(\mathrm{B})=\phi$, it comes out that $\mathrm{Fu}(\mathrm{x}) \square \subset \mathrm{A}$ and so $\mathrm{G} \square \subset \mathrm{Fu}+(\mathrm{A})$. Thus we proved that for any $\mathrm{x} \square \in$ $\mathrm{Fu}+(\mathrm{A})$, there is an open set $\mathrm{G}$ of $\mathrm{X}$ containing $\mathrm{x}$ such that $\mathrm{G} \square \subset \mathrm{Fu}+(\mathrm{A})$. Hence, $\mathrm{Fu}+(\mathrm{A})$ is an open set in $\mathrm{X}$. Similarly, $F u+(B)$ is also an open set in $X$. Since $F u$ is surjective, we get that $X=F u+(Y)=F u+(A \cup B)$ and so $\mathrm{X}$ is separable, which is a contradiction.

Theorem4.7. If Fu: $\mathrm{X} \square \rightarrow \mathrm{Y}$ is an ultra upper (lower) contra continuous punctually connected surjective multifunction and $\mathrm{X}$ is connected, then $\mathrm{Y}$ is connected.

Proof: Since u.u.c.c $\square \Rightarrow$ u.u.w.c, the conclusion follows from the above Theorem 3.4.

\section{References}

[1]. M.C.Dutta., Contribution to theory of bitopological spaces, Ph.D Thesis, Pilani, 1971.

[2]. J.C.Kelli., Bitopological Spaces, Pro.London Math.Soc,13(1963),71- 89.

[3]. M.Lellis Thivagar., Generalization of $(1,2) \alpha$-continuous functions, Pure and Applied Mathematika Sciences 33 (1991),55-63.

[4]. G.Navalagi, M.Lellis Thivagar and R.RajaRajeswari., (1,2) $\alpha$ - Hy- perconnected spaces, International Journal of Mathematics and Anal- ysis, Vol.3 (2006), $120-129$.

[5]. G.Navalagi, M.Leelis Thivagar and R.RajaRajeswari., On ultra multifunctios in bitopological spaces, International Journal of Mathe- matics, Computer Science and Information Technology Vol.1,No.1(2008),69- 74.

[6] V.Popa., A note on weakly and almost continuous multifunc- tions,Univ.u Novom sadu, Zb.Rad.Priorod. - Mat.Fak.Ser.Mat.21, 2(1991), 31-38.

[7] V.Popa and T.Noiri., On upper and lower weakly-continuous mul- tifunctions, Novi.Sad.J.Math ,Vol.32, No.1 (2002), 7-24.

[8] R.RajaRajeswari.,Bitopological concepts of some separation prop- erties, Ph.D Thesis, Madurai Kamaraj University, Madurai, India, 2009.

[9] R.RajaRajeswari.,On Some properties of Ultra weakly continuous multifunctions, Asian European Journal of Mathematics, Vol.4, No.1 (2011), $165-171$.

[10] M.S.Sarask, N.Gowrisankar and N.Rajesh., on upper and lower $\gamma$ - continuous multifunctions, Int.J.contemp.Math.Sciences, Vol.5 (2010), No.6, 281 - 288. 